Article

\title{
Effects of Dietary Astaxanthin Supplementation on Energy Budget and Bioaccumulation in Procambarus clarkii (Girard, 1852) Crayfish under Microcystin-LR Stress
}

\author{
Zhenhua An *, Yingying Zhang and Longshen Sun \\ College of Animal Science and Technology, Yangzhou University, Yangzhou 225009, China; \\ zhangyingying@yzu.edu.cn (Y.Z.); lssun@yzu.edu.cn (L.S.) \\ * Correspondence: anzhenhua@yzu.edu.cn; Tel.: +86-514-8797-2208; Fax: +86-514-8735-0440
}

Received: 7 May 2018; Accepted: 21 June 2018; Published: 4 July 2018

\begin{abstract}
This research aimed to study the effects of astaxanthin on energy budget and bioaccumulation of microcystin-leucine-arginine (microcystin-LR) in the crayfish Procambarus clarkii (Girard, 1852). The crayfish $(21.13 \pm 4.6 \mathrm{~g})$ were cultured under microcystin-LR stress $(0.025 \mathrm{mg} / \mathrm{L})$ and were fed with fodders containing astaxanthin $(0,3,6,9$, and $12 \mathrm{mg} / \mathrm{g})$ for 8 weeks in glass tanks (350 $\mathrm{mm} \times 450 \mathrm{~mm} \times 150 \mathrm{~mm}$ ). Accumulations of microcystin-LR were measured in different organs of $P$. clarkii. The results suggested that astaxanthin can significantly improve the survival rate and specific growth rate (SGR) of P. clarkii $(p<0.05)$. The dietary astaxanthin supplement seems to block the bioaccumulation of microcystin-LR in the hepatopancreas and ovaries of $P$. clarkii to some extent $(p<0.05)$. Astaxanthin content of $9-12 \mathrm{mg} / \mathrm{g}$ in fodder can be a practical and economic choice.
\end{abstract}

Keywords: microcystin-LR; Procambarus clarkii; energy budget; astaxanthin

Key Contribution: Astaxanthin in the diet was used to degrade the oxidative stress caused by microcystin-LR, and bioaccumulation was significantly affected by the astaxanthin content. The appropriate content of astaxanthin in feed may be around 9-12 $\mathrm{mg} / \mathrm{g}$ and it may make the crayfish Procambarus clarkii a more secure food for people.

\section{Introduction}

In China, cyanobacteria blooms have often been observed in some large lakes around Jiangsu province. These lakes and nearby ponds are also characterized by the presence of cultured red swamp Procambarus clarkii (Girard, 1852). As the most invasive freshwater crayfish in the world, P. clarkii is supposed to be tolerant to extreme conditions and is easily cultured, even in water where some cyanobacteria blooms occur [1]. Microcystins, as a group of cyclic polypeptides, are the most common cyanotoxins produced by several genera of cyanobacteria. Several studies have shown that exposure to microcystins can either directly kill organisms or decrease their resistance to bacterial or viral infections [2] and to some extent postpone the creatures' growth speed. Perhaps that is why P. clarkii in nutrient-enriched waters with cyanobacteria blooms always grow slowly and weakly. However, there are also studies suggesting that the $P$. clarkii individuals can feed on microalgae and accumulate toxins in their tissues, without showing any apparent changes in their behavior or vitality [3]. Considering the enormous crayfish consumption in China, this makes the presence of microcystins a serious problem for $P$. clarkii culture and safe consumption in this area.

Astaxanthin, as a useful antioxidant [4] is supposed to be a key composition that can make a great contribution to growth performance, maturation, and carapace color of crayfish [5]. It is also 
reported that astaxanthin can relieve the negative circumstance stress on juvenile kuruma shrimp Marsupenaeus japonicus [6] and astaxanthin contents increased significantly within the interval between the juvenile stages I and II in the embryonic development of crayfish Astacus leptodactylus [7]. In this study, the effects of astaxanthin on energy budget and microcystin-leucine-arginine (microcystin-LR) bioaccumulation of the crayfish P. clarkii were measured. Our aims were to develop protocols to accelerate the microcystin-LR depuration of crayfish P. clarkii and assess the effects of astaxanthin. The results may provide a reference for the astaxanthin promotion in P. clarkii cultures.

\section{Results}

\subsection{Growth}

During the experiment, some crayfish stopped wiggling antennae and crouched. The experiment showed that after nearly two months of poisoning, the reactivity and movement of some tested crayfish became slower and they subsequently died. The survival ratios of the experiment are shown in Table 1 .

Table 1. The survival ratios of Procambarus clarkii (Girard, 1852) fed on a diet with different astaxanthin (Ax) contents $(0,3,6,9,12 \mathrm{mg} / \mathrm{g})$ under microcystin-leucine-arginine (microcystin-LR) stress (25 ug/L) $\left(\right.$ mean \pm S.E). ${ }^{1}$

\begin{tabular}{cccccc}
\hline Ax Content mg/g & $\mathbf{0}$ & $\mathbf{3}$ & $\mathbf{6}$ & $\mathbf{9}$ & $\mathbf{1 2}$ \\
\hline Survival ratio $\%$ & $77.78 \pm 4.81^{\mathrm{a}}$ & $83.33 \pm 8.33^{\mathrm{ab}}$ & $86.11_{\mathrm{a}, \mathrm{b}}^{ \pm 12.73}$ & $94.44 \pm 4.81^{\mathrm{b}}$ & $97.22 \pm 4.81^{\mathrm{b}}$ \\
\hline $\begin{array}{l}1 \text { Values (expressed as mean } \pm \text { S.E., } n=3) \\
\text { other }(p<0.05) .\end{array}$
\end{tabular}

The maximum and minimum specific growth rate (SGR) $\left(\mathrm{SGR}_{\mathrm{w}}\right.$ and $\mathrm{SGR}_{\mathrm{e}}$, respectively) occurred in treatment $\mathrm{E}(12 \mathrm{mg} / \mathrm{L}$ astaxanthin concentration ration). Stepwise regression analysis showed that $\mathrm{SGR}_{\mathrm{w}}$ and $\mathrm{SGR}_{\mathrm{e}}$ increased with increasing astaxanthin concentration (Figure 1). The relationship among $\mathrm{SGR}_{\mathrm{W}}$ and $\mathrm{SGR}_{\mathrm{e}}$ and astaxanthin concentration (Ac \%) can be described by the regression equations:

$$
\begin{aligned}
& \operatorname{SGR}_{\mathrm{w}}=0.191+25.867 \mathrm{Ac}\left(r^{2}=0.899, n=5\right) \\
& \mathrm{SGR}_{\mathrm{e}}=0.153+25.113 \mathrm{Ac}\left(r^{2}=0.863, n=5\right)
\end{aligned}
$$

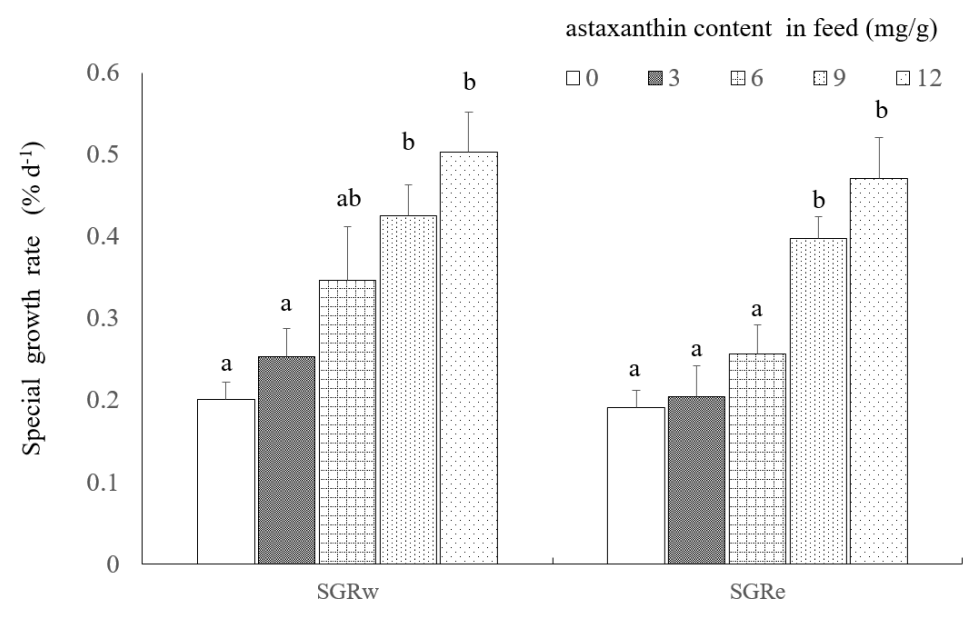

Figure 1. The effects of astaxanthin content $(0,3,6,9,12 \mathrm{mg} / \mathrm{g})$ in feed on the specific growth rate $\left(\mathrm{SGR}_{\mathrm{w}}\right.$ and $\mathrm{SGR}_{\mathrm{e}}$ ) (expressed as mean \pm S.E., $n=3$ ) of the crayfish Procambarus clarkii (Girard, 1852) under microcystin-LR stress ( $25 \mathrm{ug} / \mathrm{L})$. Histograms sharing a common letter on top are not significantly different $(p>0.05)$. 
The results of one-way ANOVA analysis showed astaxanthin concentrations in the diet had significant effects on $\mathrm{SGR}_{\mathrm{w}}$ and $\mathrm{SGR}_{\mathrm{e}}$ values of P. clarkii $(p<0.05)$. The $\mathrm{SGR}_{\mathrm{w}}$ and $\mathrm{SGR}_{\mathrm{e}}$ values in treatments $\mathrm{D}$ and $\mathrm{E}$ were significantly higher than the treatments $\mathrm{A}$ and $\mathrm{B}(p<0.05)$ (Figure 2).

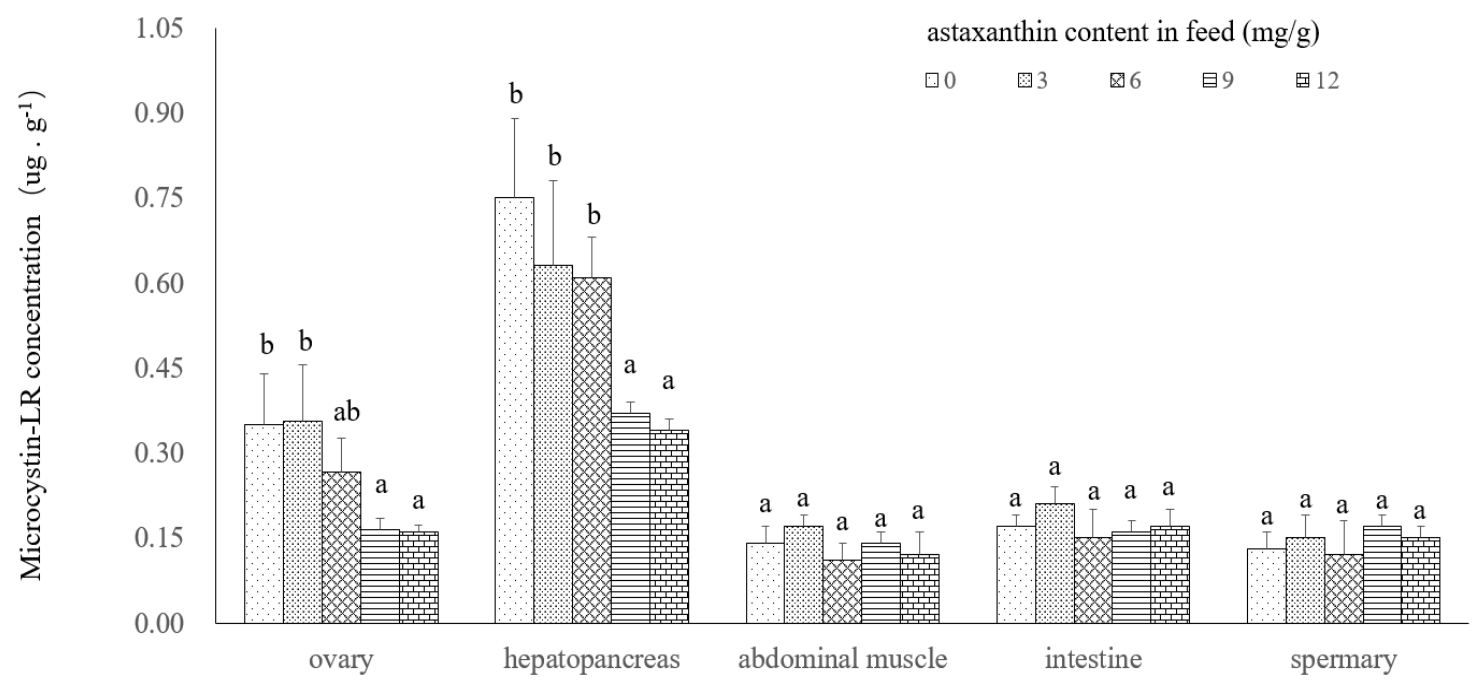

Figure 2. Biological enrichment of microcystin-LR (expressed as mean \pm S.E., $n=3$ ) in the hepatopancreas, muscle, intestine, ovary and spermary of Procambarus clarkii (Girard, 1852). Histograms sharing a common letter on top in the same tissue are not significantly different $(p>0.05)$.

\subsection{Microcystin Depuration}

In the experiment, microcystin-LR was observed in all organs/tissues analyzed, but mostly in the hepatopancreas and ovary. The microcystin contents were observed to decrease in the following order: hepatopancreas $>$ ovary $>$ intestine $>$ abdominal muscle (Figure 2). The microcystin-LR contents in hepatopancreas and ovary were significantly higher than others and they can be considered as indicators of microcystin-LR stress. The results in abdominal muscle were slightly different to those of the spermary. The results of one-way ANOVA analysis showed that the astaxanthin concentration in diet had a significant effect on bioaccumulation of $P$. clarkii in the ovary and hepatopancreas $(p<0.05)$.

\subsection{Energy Allocation}

The energy budget in the tested crayfish changed with the different astaxanthin concentrations in diet (Table 2). At treatments $E$ and $D$ the ratio of $G / C$ in treatment were significantly higher than in the other groups. The ratio of $\mathrm{F} / \mathrm{C}$ in treatments suggested no significant differences between each other $(p>0.05)$. The highest ratio of $\mathrm{R} / \mathrm{C}$ occurred in treatment $\mathrm{A}$ and it was significantly higher than in treatments $\mathrm{D}$ and $\mathrm{E}(p<0.05)$. 
Table 2. Daily energy budgets of Procambarus clarkii fed on diets with different astaxanthin contents $(0,3,6,9,12 \mathrm{mg} / \mathrm{g})(\mathrm{mean} \pm \mathrm{S} . \mathrm{E}){ }^{1}$.

\begin{tabular}{|c|c|c|c|c|c|c|}
\hline Astaxanthin Content $\mathrm{mg} / \mathrm{g}$ & $C^{2}$ & $\mathrm{G}^{3}$ & $F^{4}$ & $E^{5}$ & $\mathrm{U}^{6}$ & $\mathbf{R}^{7}$ \\
\hline 0 & $4304.24 \pm 177.48^{\mathrm{a}}$ & $612.47 \pm 95.0^{\mathrm{a}}$ & $1027.15 \pm 105.80^{\mathrm{a}}$ & $120.56 \pm 14.02^{\mathrm{a}}$ & $182.17 \pm 14.02^{\mathrm{a}}$ & $2361.89 \pm 146.96^{b}$ \\
\hline 3 & $4413.37 \pm 151.21^{\mathrm{a}}$ & $678.24 \pm 107.11^{\mathrm{a}}$ & $1079.89 \pm 77.55^{\mathrm{a}}$ & $141.24 \pm 23.59^{a}$ & $186.47 \pm 13.59^{\mathrm{a}}$ & $2327.53 \pm 139.19^{b}$ \\
\hline 6 & $4315.56 \pm 147.14^{\mathrm{a}}$ & $845.24 \pm 125.24^{\mathrm{a}, \mathrm{b}}$ & $1024.54 \pm 86.78^{a}$ & $155.73 \pm 16.10^{\mathrm{a}}$ & $196.59 \pm 16.10^{\mathrm{a}}$ & $2093.46 \pm 170.37^{a, b}$ \\
\hline 9 & $4532.36 \pm 284.82^{a}$ & $1048.12 \pm 76.37^{b}$ & $1263.78 \pm 97.73^{a}$ & $221.47 \pm 31.68^{b}$ & $201.21 \pm 21.68^{\mathrm{a}}$ & $1797.78 \pm 114.54^{\mathrm{a}}$ \\
\hline 12 & $4557.24 \pm 147.97^{\mathrm{a}}$ & $1175.11 \pm 92.45^{b}$ & $1243.45 \pm 107.73^{a}$ & $233.45 \pm 21.68^{b}$ & $214.53 \pm 21.68^{\mathrm{a}}$ & $1690.70 \pm 114.54^{\mathrm{a}}$ \\
\hline
\end{tabular}

${ }^{1}$ Values (expressed as mean \pm S.E., $n=3$ ) with different letters superscript in the same column are significantly different from each other $(p<0.05) ;{ }^{2} \mathrm{C}\left(\mathrm{J} \cdot \mathrm{g}^{-1} \cdot \mathrm{d}^{-1}\right)=\mathrm{energy} \mathrm{consumed}^{\mathrm{s}}$ in food; ${ }^{3} \mathrm{G}\left(\mathrm{J} \cdot \mathrm{g}^{-1} \cdot \mathrm{d}^{-1}\right)=$ energy deposited as growth; ${ }^{4} \mathrm{~F}\left(\mathrm{~J} \cdot \mathrm{g}^{-1} \cdot \mathrm{d}^{-1}\right)=$ energy lost from feces; ${ }^{5} \mathrm{E}\left(\mathrm{J} \cdot \mathrm{g}^{-1} \cdot \mathrm{d}^{-1}\right)=$ energy lost from molt; ${ }^{6} \mathrm{U}\left(\mathrm{J} \cdot \mathrm{g}^{-1} \cdot \mathrm{d}^{-1}\right)=\mathrm{energy}$ lost from excretion; ${ }^{7} \mathrm{R}\left(\mathrm{J} \cdot \mathrm{g}^{-1} \cdot \mathrm{d}^{-1}\right)=$ energy used in respiration. 
The results suggested that ratios of $\mathrm{G} / \mathrm{C}$ and $\mathrm{R} / \mathrm{C}$ were significantly affected by the astaxanthin concentration in the diet $(p<0.05)$. Due to the different numbers of molts, the ratios of $\mathrm{E} / \mathrm{C}$ in treatment A, B, and C were significantly lower than D and E $(p<0.05)$.

\section{Discussion}

As an organic toxin, microcystin-LR is difficult to degrade and accumulates easily in some aquatic products [8,9], causing public concern about the pollution problems caused by microcystin. Although microcystins are produced by several genera of cyanobacteria, such as Microcystis, Anabaena, and Oscillatoria, the most commonly reported species is Microcystis aeruginosa. This species is inclined to live in relatively quiet waters and forms surface water blooms between summer and autumn [10]. In China, around the Changjiang plain, most $P$. clarkii crayfish are cultured in ponds without fast water pump facilities, and that makes the microcystin problem of $P$. clarkii more serious in this area.

There are many studies suggesting that the sensitivity of aquatic animals to microcystins changes depending on the organism [11], the variant, and the mode of exposure [12]. The content of microcystins in different organs can be an indicator of microcystins stress and the organism can also perform depuration of microcystins to some extent [13]. There are several studies on depuration of microcystins in fish and other aquatic organisms, showing a decrease in microcystin content in several organs (liver and muscle) in a time-dependent manner $[14,15]$. It has been suggested that the most affected organ with regard to the lipid peroxidation caused by microcystin-LR is the liver [16]. In this study, we used the purified microcystin-LR and found the hepatopancreas and ovary to accumulate with toxins than other organs; and this may be the reason why the occurrence of cyanobacteria blooms in the crayfish culture ponds often results in a fall in production and size of captures. The spermary seems to differ from the ovary and its toxin concentration was almost the same as in the muscles. Considering the abundant lipid content of the crayfish ovary during breeding season [17], this finding may be due to the difference of lipid content and the metabolic regulation mechanisms of P. clarkii.

Microcystin exposure has been reported to cause oxidative stress to animals [18,19]. In our research the energy allocated for respiration $(R)$ was significantly decreased with the increasing dietary astaxanthin supplementation $(p<0.05)$. This could implicate that astaxanthin could degrade the oxidative stress caused by microcystin-LR to some extent. There was some research suggesting that astaxanthin could also enhance the specific growth rate and relieve the fresh water-osmotic stress in juvenile kuruma shrimp Marsupenaeus japonicus [7]. Some research also reported that an astaxanthin-supplemented diet could not only shorten the molting cycle of the juvenile crustacean but also the postlarval stages of some shrimps such as Penaeus japonicus [20]. This research showed the similar results that the energy allocated for molt (E) was significantly higher in the treatments where the crayfish were fed with high dietary astaxanthin supplementation $(p<0.05)$. In sum, astaxanthin could apparently reduce the energy used for respiration and increase the growth and molting ratios in total energy consumed in food.

With the rapidly development of the astaxanthin compositing industry and the falling costs of astaxanthin, it is more and more practical to use the astaxanthin in crustacean culture. Based on the growth and energy allocation results, the appropriate supplement of astaxanthin in feed may be around $10 \mathrm{mg} / \mathrm{g}$. In this way, astaxanthin, which is usually considered responsible for crayfish coloration, will also make the crayfish P. clarkii a safer food for human consumption.

\section{Material and Methods}

\subsection{Source of Animals and Acclimation}

The experiments were conducted from 1 September to 27 October 2015, at the Aquaculture Research Laboratory, Yangzhou University. The crayfish were captured in the suburb of Baoying lake, Yangzhou city and cultivated at a temperature $24 \pm 2{ }^{\circ} \mathrm{C}$ in several fiberglass tanks with tap water aerated for $48 \mathrm{~h}$, and the water $\mathrm{pH}$ adjusted to $7.5 \pm 0.5$. During the acclimation period, the animals 
were fed twice a day (at $08.00 \mathrm{~h}$ and $18.00 \mathrm{~h}$ ) with commercial feed provided by Fuyuda corporation (41.70\% crude protein, $7.67 \%$ crude lipid, $7.89 \%$ ash, moisture < 2.70\%; energy $21.55 \mathrm{~kJ} / \mathrm{g}$ dry mass). Aeration was provided continuously and one-third of the water volume in all the experiment tanks was exchanged every day. Dissolved oxygen was maintained above $4.0 \mathrm{mg} / \mathrm{L}$.

\subsection{Experimental Design and Procedure}

The original pure lyophilized microcystin-LR was bought from Express Technology Co., Ltd., (Beijing, China) and was prepared into $10 \mathrm{mg} / \mathrm{L}$ of mother solution with double-distilled water. Microcystin analysis was conducted by ELISA test. The ELISA test kits were bought from J \& Q Environment Corporation (Beijing, China). This method had a sensitivity of $0.1 \mathrm{ng} / \mathrm{mL}$. The astaxanthin capsules were brought from Fujian Corona Technology Corporation (Fuzhou, Fujian Province, China). Each capsule contained astaxanthin $60 \mathrm{mg}$ (alga extraction), and soybean oil $440 \mathrm{mg}$. In making the feed, we squeezed the capsules and mixed the contents well with the same batch commodity feed which was also used in acclimation. The feed slowly absorbed the oil through its capillaries and within $1 \mathrm{~h}$ there was no discernible solution in water. We also added a little soybean oil in different feeds to compensate for the energy differences caused by astaxanthin adjunction.

Finally, five astaxanthin feed concentrations $(0,3,6,9$ and $12 \mathrm{mg} / \mathrm{g}$; treatments A, B, C, D, and E) were made, and each treatment had three parallel groups. Each parallel group had 12 crayfish. Totally 180 crayfish (with average weight $21.13 \pm 4.6 \mathrm{~g}$ and male: female $=1: 1$ ) were used and there were no significant differences between groups. The acclimation was followed by starvation for $24 \mathrm{~h}$. The initial body weight of each experimental animal was measured. The experiments were carried out in glass aquaria (35 cm width $\times 45 \mathrm{~cm}$ length $\times 15 \mathrm{~cm}$ depth), the solution in each experimental group was over $15 \mathrm{~L}$ with $0.025 \mathrm{mg} / \mathrm{L}$ microcystin-LR concentration and one-third of the water volume in all the experiment tanks was exchanged every day with siphoned feces and uneaten feed to stabilize the microcystin-LR concentration. Aeration was provided continuously, and dissolved oxygen was maintained above $4.0 \mathrm{mg} / \mathrm{L}$.

During the experiment the animals were fed ad libitum twice a day (08:00 $\mathrm{h}$ and 18:00 $\mathrm{h}$ ) with the feed. The experimental temperature was $24 \pm 2{ }^{\circ} \mathrm{C}$. The number of dead crayfish was recorded per $24 \mathrm{~h}$ and at finally 22 crayfish (12.22\%) were dead in the experiment. At the end of the culture, six living crayfish (half male and half female) were picked up in each parallel group. In total, 18 crayfish were prepared for bioaccumulation test in each treatment. The concentrations of microcystin-LR in the hepatopancreas, intestine, gonads (ovary or spermary), and abdominal muscle of the crayfish were measured by the means of ELISA. The analysis of microcystin content was conducted on samples of similar fresh weight ( $0.5 \mathrm{~g}$ for intestine and spermary; $1.0 \mathrm{~g}$ for hepatopancreas, abdomen, and ovaries) obtained by pooling the organs/tissues of three crayfish. Each tissue was tested with three samples in each treatment. The ovaries or spermaries were prepared separately from nine females and nine males. Other tissues were randomly sampled from nine of the former crayfish from which gonads had been obtained. Half the crayfish provided both gonads and tissues (hepatopancreas, abdomen muscle, and intestine) for analysis.

\subsection{Energy Determination and Estimation of Energy Budget}

During the 56-day course of the experiment, the weight of each ration was recorded. Uneaten feed, feces, and molt (exuvia) were separated and removed by siphon to avoid decomposition, dried at $65{ }^{\circ} \mathrm{C}$, shattered, weighed, and kept for analysis of energy and nitrogen content. At the end of the experiment, the animals were starved for $24 \mathrm{~h}$, and then weighed and dried at $65{ }^{\circ} \mathrm{C}$ for $48 \mathrm{~h}$ and shattered for measurement. The energy contents of the crayfish bodies, feed, and feces were measured with a Parr 6300 Oxygen Bomb Calorimeter (Parr, Moline, IL, USA). The energy budget was calculated by the following equation [21]:

$$
C=G+F+U+R+E
$$


where $C$ is the energy consumed in food; $G$ is the energy deposited as growth; $F$ is the energy lost in feces; $\mathrm{E}$ is the energy lost in molt; $\mathrm{U}$ is the energy lost in excretion; and $\mathrm{R}$ is the energy used for respiration. The value of $\mathrm{C}$ and $\mathrm{F}$ can be calculated by the weight of the samples of food intake, feces weight, and energy content per gram. G can be calculated by the following equation:

$$
\mathrm{G}=(\mathrm{Fw} \times \mathrm{Fe})-(\mathrm{Iw} \times \mathrm{Ie})
$$

where Fw and Iw are final body weight and initial body weight of the crayfish, respectively; Fe and Ie are the energy content per germ of final body and initial body of the crayfish, respectively.

$\mathrm{F}$ and $\mathrm{E}$ were calculated by the following equation:

$$
\begin{aligned}
& \mathrm{F}=\mathrm{Pw} \times \mathrm{Pe} ; \\
& \mathrm{E}=\mathrm{Ew} \times \mathrm{Ee}
\end{aligned}
$$

where Pw and Ew are final collected feces weight and crustaceous membrane weight of the crayfish, respectively; Pe and Ee are the energy content per germ of feces and crustaceous membrane of the crayfish, respectively.

The nitrogen contents of the crayfish bodies, food, and feces were measured with a Vario Elcube elemental analyzer (Elementar, Germany) at the test center of Yangzhou University. The estimation of $\mathrm{U}$ was based on the nitrogen budget equation [22]:

$$
\mathrm{U}=(\mathrm{CN}-\mathrm{GN}-\mathrm{FN}-\mathrm{EN}) \times 24,830
$$

where $\mathrm{CN}$ is the nitrogen consumed from food; FN is the nitrogen lost in feces; $\mathrm{GN}$ is the nitrogen deposited in the body; EN is the nitrogen deposited in the molt; and 24,830 is the energy content $\left(\mathrm{J} \cdot \mathrm{g}^{-1}\right)$ of excreted nitrogen.

The value of $R$ was calculated by the energy budget equation:

$$
\mathrm{R}=\mathrm{C}-\mathrm{G}-\mathrm{F}-\mathrm{U}-\mathrm{E}
$$

\subsection{Calculation and Data Analysis}

Specific growth rate in terms of weight (SGRw) and energy (SGRe) were calculated as:

$$
\begin{gathered}
\operatorname{SGRw}\left(\% \text { day }^{-1}\right)=100 \times\left(\ln \mathrm{W}_{2}-\ln \mathrm{W}_{1}\right) / \mathrm{D} \\
\operatorname{SGRe}\left(\% \text { day }^{-1}\right)=100 \times\left(\ln \mathrm{E}_{2}-\ln \mathrm{E}_{1}\right) / \mathrm{D}
\end{gathered}
$$

where $W_{2}$ and $W_{1}$ are the final and initial wet body weight of the crayfish, respectively; $E_{2}$ and $E_{1}$ are the final and initial body energy of the crayfish, respectively; and D is the duration of the experiment. The data were analyzed by SPSS for Windows (Version 19.0) statistical package (SPSS Inc., Chicago, IL, USA). Inter-treatment differences of survival ratios, SGRw, SGRe, concentration of microcystin-LR, and energy allocation were analyzed with one-way ANOVA followed by post-hoc Tukey multiple range tests. Differences were considered significant if $p<0.05$.

Author Contributions: Z.H.A. designed the study. L.S.S. conceived and designed the experiments and collected the samples. Z.H.A. and Y.Y.Z. analyzed the data and contributed reagents, materials, and analysis tools, and provided valuable input into the study design and the manuscript.

Acknowledgments: Jiangsu Fisheries Reasearch System (Red Swamp Crayfish) JFRS-03 and Jiangsu Agricultural Science and Technology Innovation Fund (JASTIF) supported this study.

Conflicts of Interest: The authors declare no conflict of interest. 


\section{References}

1. Gherardi, F.; Lazzara, L. Effects of the density of an invasive crayfish (P. clarkii) on a pelagic and surface microalgae in a Mediterranean wetland. Arch. Hydrobiol. 2006, 165, 401-414. [CrossRef]

2. Carmichael, W.W. Toxic Microcystis and the Environment; Watanabe, M.F., Harada, K., Carmichael, W.W., Fujiki, H., Eds.; CRC Press: Boca Raton, FL, USA, 1996; p. 111.

3. Vasconcelos, V.; Oliveira, S.; Teles, F.O. Impact of a toxic and non-toxic strain of Microcystis aeruginosa on the crayfish Procambarus clarkii. Toxicon 2001, 39, 1461-1470. [CrossRef]

4. Yuan, J.P.; Peng, J.; Yin, K.; Wang, J.H. Potential health-promoting effects of astaxanthin: A high-value carotenoid mostly from microalgae. Mol. Nutr. Food Res. 2011, 55, 150-165. [CrossRef] [PubMed]

5. Kaldre, K.; Haugjärv, K.; Liiva, M.; Gross, R. The effect of two different feeds on growth, carapace colour, maturation and mortality in marbled crayfish (Procambarus fallax f. virginalis). Aquac. Int. 2015, 23, 185-194. [CrossRef]

6. Wang, W.; Ishikawa, M.; Koshio, S.; Yokoyama, S.; Hossain, M.S.; Moss, A.S. Effects of dietary astaxanthin supplementation on juvenile kuruma shrimp, Marsupenaeus japonicus. Aquaculture 2018, 491, 197-204. [CrossRef]

7. Berticat, O.; Nègre-Sadargues, G.; Castillo, R. The metabolism of astaxanthin during the embryonic development of the crayfish Astacus leptodactylus Eschscholtz (Crustacea, Astacidea). Comp. Biochem. Physiol. Part B Biochem. 2000, 127, 309-318. [CrossRef]

8. Xu, H.B.; Sui, H.X.; Gao, S.R. Primary experimental study on bioaccumulation of microcystin in Cyprinus carpio L. Chin. J. Food Hyg. 2003, 15, 202-204.

9. Li, X.G.; Zhou, G.; Zhou, J.L. Preliminary study on the Accumulation and Biodepuration of Microcystins in Tilapia. J. Hydroecol. 2010, 3, 67-70.

10. Krishnamurthy, T.; Carmichael, W.W.; Sarver, E.W. Toxic peptides from freshwater cyanobacteria (blue-green-algae). I. Isolation, purification and characterization of peptides from Microcystis aeruginosa and Anabaena flos-aquae. Toxicon 1986, 24, 865-873. [CrossRef]

11. Hansson, L.A.; Gustafsson, S.; Rengefors, K.; Bomark, L. Cyanobacterial chemical warfare affects zooplankton community composition. Fresh Water Biol. 2007, 52, 1290-1301. [CrossRef]

12. Codd, G.A.; Poon, G.K. Cyanobacterial toxins. In Biochemistry of the Algae and Cyanobacteria; Rogers, L.J., Gallon, J.R., Eds.; Oxford Science Publishers, Clarendon Press: Oxford, UK, 1998; pp. 283-296.

13. Chen, J.; Xie, P. Tissue distributions and seasonal dynamics of the hepatotoxic microcystins-LR and-RR in two freshwater shrimps, Palaemon modestus and Macrobrachium nipponensis, from a large shallow, eutrophic lake of the subtropical China. Toxicon 2005, 45, 615-625. [CrossRef] [PubMed]

14. Smith, J.L.; Haney, J.F. Foodweb transfer, accumulation, and depuration of microcystins, a cyanobacterial toxin, in pumpkinseed sunfish (Lepomis gibbosus). Toxicon 2006, 48, 580-589. [CrossRef] [PubMed]

15. Elena, T.; Silvia, B.; Sara, B. Depuration of microcystin-LR from the red swamp crayfish Procambarus clarkii with assessment of its food quality. Aquaculture 2008, 285, 90-95.

16. Huang, C.H.; Chang, R.J.; Huang, S.L.; Chen, W.L. Dietary vitamin E supplementation affects tissue lipid peroxidation of hybrid tilapia. Oreochromis niloticus $\times$ O. aureus. Comp. Biochem. Physiol. Part B 2003, 134, 265-270. [CrossRef]

17. Garciaguerrero, M.; Racotta, I.S.; Villarreal, H. Variation in lipid, protein, and carbohydrate content during the embryonic development of the crayfish Cherax Quadricarinatus (Decapoda: Parastacidae). J. Crustacean Biol. 2003, 23, 1-6. [CrossRef]

18. Cazenave, J.; Bistoni, M.A.; Pesce, S.F.; Wunderlin, D.A. Differential detoxification and antioxidant response in diverse organs of Corydoras paleatus experimentally exposed to microcystin-RR. Aquatic Toxicol. 2006, 76, 1-12. [CrossRef] [PubMed]

19. Prieto, A.I.; Pichardo, S.; Jos, A.; Moreno, I.; Camean, A.M. Time-dependent oxidative stress responses after acute exposure to toxic cyanobacterial cells containing microcystins in tilapia fish (Oreochromis niloticus) under laboratory conditions. Aquatic Toxicol. 2007, 84, 337-345. [CrossRef] [PubMed]

20. Petit, H.; Negre-Sadargues, G.; Castillo, R.; Trilles, J.P. The effects of dietary astaxanthin on growth and moulting cycle of postlarval stages of the prawn, Penaeus Japonicus (Crustacea, Decapoda). Comp. Biochem. Physiol. Part A Physiol. 1997, 117, 539-544. [CrossRef] 
21. Carfoot, T.H. Animal Energetics; Academic Press: New York, NY, USA, 1987; pp. 407-515.

22. Levine, D.M.; Sulkin, S.D. Partitioning and utilization of energy during the larval development of the xanthid crab, Rithropanopeus harrisii (Gould). J. Exp. Mar. Biol. Ecol. 1979, 40, 247-257. [CrossRef]

(C) 2018 by the authors. Licensee MDPI, Basel, Switzerland. This article is an open access article distributed under the terms and conditions of the Creative Commons Attribution (CC BY) license (http://creativecommons.org/licenses/by/4.0/). 